\title{
Flower litters of alpine plants affect soil nitrogen and phosphorus rapidly in the eastern Tibetan Plateau
}

\author{
Jinniu Wang ${ }^{1,2}$, Bo Xu ${ }^{1,3}$, Yan Wu ${ }^{1}$, Jing Gao ${ }^{1,3}$, and Fusun Shi ${ }^{1}$ \\ ${ }^{1}$ CAS Key Laboratory of Mountain Ecological Restoration and Bioresource Utilization \& Ecological Restoration \\ and Biodiversity Conservation Key Laboratory of Sichuan Province, Chengdu Institute of Biology, Chinese \\ Academy of Sciences, Chengdu 610041, China \\ ${ }^{2}$ International Centre for Integrated Mountain Development (ICIMOD), P.O. Box 3226, Kathmandu, Nepal \\ ${ }^{3}$ University of Chinese Academy Sciences, Beijing 100049, China \\ Correspondence to: Fusun Shi (shifs@cib.ac.cn)
}

Received: 28 February 2016 - Published in Biogeosciences Discuss.: 15 April 2016

Revised: 31 July 2016 - Accepted: 30 August 2016 - Published: 10 October 2016

\begin{abstract}
Litters of reproductive organs have rarely been studied despite their role in allocating nutrients for offspring reproduction. This study determines the mechanism through which flower litters efficiently increase the available soil nutrient pool. Field experiments were conducted to collect plant litters and calculate biomass production in an alpine meadow of the eastern Tibetan Plateau. C, N, P, lignin, cellulose content, and their relevant ratios of litters were analyzed to identify their decomposition features. A pot experiment was performed to determine the effects of litter addition on the soil nutrition pool by comparing the treated and control samples. The litter-bag method was used to verify decomposition rates. The flower litters of phanerophyte plants were comparable with non-flower litters. Biomass partitioning of other herbaceous species accounted for $10-40 \%$ of the aboveground biomass. Flower litter possessed significantly higher $\mathrm{N}$ and $\mathrm{P}$ levels but less $\mathrm{C} / \mathrm{N}, \mathrm{N} / \mathrm{P}$, lignin / N, and lignin and cellulose concentrations than leaf litter. The litter-bag experiment confirmed that the flower litters of Rhododendron przewalskii and Meconopsis integrifolia decompose approximately 3 times faster than mixed litters within 50 days. Pot experiment findings indicated that flower litter addition significantly increased the available nutrient pool and soil microbial productivity. The time of litter fall significantly influenced soil available $\mathrm{N}$ and $\mathrm{P}$, and soil microbial biomass. Flower litters fed the soil nutrition pool and influenced nutrition cycling in alpine ecosystems more efficiently because of their non-ignorable production, faster decomposition rate, and higher nutrient contents compared with non-flower lit-
\end{abstract}

ters. The underlying mechanism can enrich nutrients, which return to the soil, and non-structural carbohydrates, which feed and enhance the transitions of soil microorganisms.

\section{Introduction}

Plant properties directly affect the productivity and function of an ecosystem in a natural environment (Chapin et al., 1986; Chapin, 2003; Berendse and Aerts, 1987; Grime, 1998). Plants continuously lose $\mathrm{N}$ and $\mathrm{P}$ in their entire life history and even during litter production and decomposition (Laungani and Knops, 2009; Richardson et al., 2009). In cold environments, litter tends to be recalcitrant (Aerts, 1997), but reproductive tissues present chemical composition that differs from vegetative parts, resulting in a markedly faster decomposition and nutrient release, with repercussions for nutrient cycling and patchiness (Buxton and Marten, 1989; Lee et al., 2011). Although inflorescences comprise only a small fraction of plant biomass and production in Arctic and alpine vegetation, the inflorescence production can be a significant proportion of the total production of species under certain special circumstances (Martínez-Yrízar et al., 1999; Fabbro and Körner, 2004; Wookey et al., 2009). High contents of $\mathrm{N}$ and $\mathrm{P}$ exist in the reproductive organs of plants, probably because of their essential roles in plant growth and formation (e.g., high protein content). The rate of decay and concentrations of nutrients in the litter determine the rate of nutrient release, which creates a positive feedback to site fer- 
tility. Hence, the chemical properties of litters from different plant organs and their correlations with decomposition rate must be determined.

The growth and health of plants in their life history have been considerably influenced by variations in the physical, chemical, and biological properties of soil, particularly around the rhizosphere. Nonetheless, soil properties can also be mediated by plants. $\mathrm{N}$ is a major constituent of several important plant substances (Vitousek and Howarth, 1991). In cold life zone ecosystems, plant biomass production is limited by $\mathrm{N}$ (Körner, 2003). The plant residue is one principal component of soil organic matter (SOM), whose decomposition can supply available $\mathrm{N}$ to plants and microorganisms. Similar to N, P is closely associated with numerous vital plant processes. Nevertheless, in most circumstances, $\mathrm{P}$ is limited because of its small concentration in soil; this element is released slowly from insoluble P but is highly demanded by plants and microorganisms (Bieleski, 1973; Richardson et al., 2009). As decomposition is a prolonged process, plants contain concentrated nutrients comparable with soil, which enhance the microbial immobilization of $\mathrm{N}$ when they provide $\mathrm{C}$ to soil microorganisms. The nature of litter determines its palatability to soil organisms, thereby influencing their composition and activity levels. Litter can also mediate the interactions between neighboring plants in infertile communities (Nilsson et al., 1999; Xiong and Nilsson, 1999), which significantly affect the biogeochemical cycle and feedback of plant-soil interaction.

Fast decay of $\mathrm{N}$-rich litters suggests that litter decay rates increase with increasing $\mathrm{N}$ content. The initial rate of nutrient release is positively correlated with the initial concentrations of $\mathrm{N}$ or P (MacLean and Wein, 1978; Aber and Melillo, 1980; Berg and Ekbohm, 1983; Yavitt and Fahey, 1986; Stohlgren, 1988). Long-term increases in $\mathrm{N}$ availability have also been reported following the additions of $\mathrm{C}$ to forests (Groffman, 1999). In agricultural systems, addition of fresh residues can stimulate the decomposition and net release of N from indigenous SOM (Haynes, 1986; Scott et al., 1996). Recently, a common-garden decomposition experiment in a wide range of subarctic plant types demonstrated that structural and chemical traits are better predictors of several high-turnover organs than structural traits alone (Freschet et al., 2012). Decomposition rates of plant litters slightly differ because of their species-specific traits and various organs, whose chemical qualities vary in a wide range of plant types and environments.

Alpine ecosystems are thermally restricted and characterized by a low material turnover rate (Körner, 2003). In a highaltitude region, plants grow in a harsh habitat that restricted their effective utilization of resources; in this regard, the total available resource is less compared with that of plants in other regions (Fabbro and Körner, 2004; Hautier et al., 2009). In long-term evolution, the allocation of accumulated carbohydrates to reproduction is an adaptation strategy, leading to the partitioning of reproductive organs, that is, the availabil-

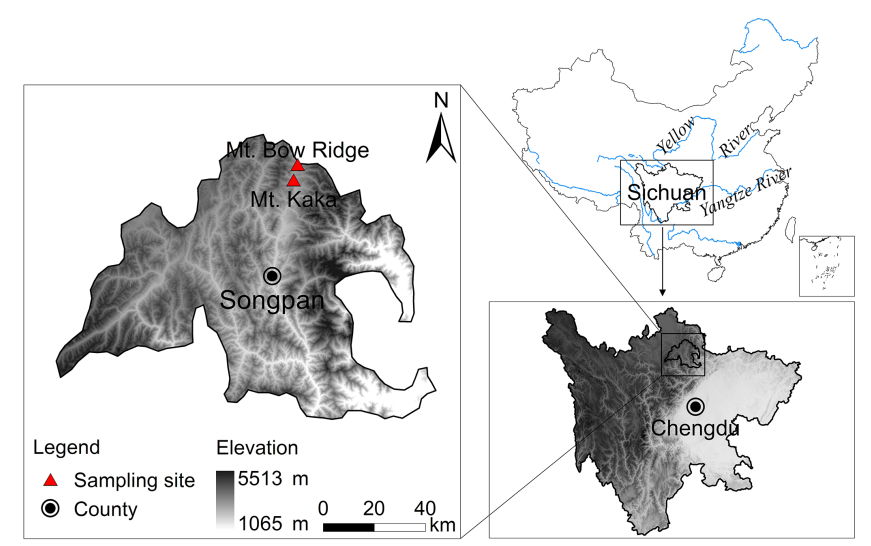

Figure 1. Location of the study sites.

ity and timely mobilization of adequate resources from the vegetative plant body to reproductive structures (Arroyo et al., 2013). Thus far, probably due to reproductive organs' comparatively minor biomass production and difficulty in being collected, studies on their decomposition have been limited particularly compared with those on leaf and other vegetative organs. In this study, we conducted comprehensive field investigation, pot experiments of litter addition, and litter-bag experiments to address the following questions.

1. Should flower litter be considered in the alpine ecosystem's biogeochemical cycles for their relatively nonnegligible biomass production and/or allocation?

2. Does flower litter of higher quality and with unique traits have faster decomposition than leaf litter?

3. Does the time of litter fall influence soil available nutrients and soil microbial productivity of alpine meadow ecosystems?

\section{Materials and methods}

\subsection{Study area}

The field site is located at the foot of Mt. Kaka, which belongs to the middle section of Minshan Mountains, eastern Tibetan Plateau (Fig. 1), with a mean annual precipitation of $720 \mathrm{~mm}$. More than $70 \%$ of precipitation falls in summer from June to August. Snowfall usually occurs from the end of September to early May next year. Vegetation presents a typical alpine meadow with numerous and unique alpine plants. Mosses are abundant and cover most of the ground. The moss layer is dominated by Polytrichum swartzii and Trematodon acutus c. mull. Vascular plants include species mainly belonging to genus Kobresia and genus Carex. Other common species are Festuca spp., Gentiana spp., and Leontopodium spp. Plant roots in this ecosystem are generally confined to the surface A-horizon $(2-20 \mathrm{~cm})$. A few dwarf shrubs are 
scattered sporadically in the meadow, e.g., Rhododendron and Salix. The soil type is dominated by Mat Cry-gelic Cambisols (i.e., silty loam inceptisol, Chinese Soil Taxonomy Research Group, 1995).

\subsection{Plant litter sampling}

During the blooming period from the end of May until midJune and from the end of July until early August, flower litters of 14 earlier flowering plants species and 15 later flowering plant species were carefully collected in 2012 at two sites, namely, Mt. Kaka $\left(103^{\circ} 42^{\prime} \mathrm{E}, 32^{\circ} 59^{\prime} \mathrm{N}\right.$; 3500$3900 \mathrm{~m}$ a.s.l.) and Bow Ridge Mountain $\left(103^{\circ} 42^{\prime} \mathrm{E}, 33^{\circ} 1^{\prime} \mathrm{N}\right.$; 3600-3850 $\mathrm{m}$ a.s.l.). In the study, four litter traps were placed under the crown of each individual shrub in different communities (five to eight individuals were chosen for the placement of litter traps), which were processed and modified based on the litterfall monitoring protocol (Muller-Landau and Wright, 2010). The litter trap was composed of one cloth bag and four support legs. A window screen (with a mesh size of $0.8 \mathrm{~mm}$ ) was used to seize the cloth bag. Its size was about $50 \mathrm{~cm}$ deep and $25 \mathrm{~cm}$ long. Four legs (made with an $80 \mathrm{~cm}$ PVC pipe) were tied with a cloth bag and frame. The frame of the opening was made of iron wire with a $3 \mathrm{~mm}$ diameter. After inserting it into the soil under the shrub's crown, the plant litter was collected twice per week, which was later sorted as flower litter and other types during the blooming period. Given the small size of herbaceous individuals, flowers were plucked at the end of the flowering phase, and their mass ratios to aboveground biomass were calculated. Freshly fallen leaves of different species were collected from the floor of the alpine meadow (i.e., mixed leaf litters, ca. $3950 \mathrm{~m}$ a.s.l.). These species were tentatively classified into five groups according to Raunkiaer's life-form system (i.e., chamephyte, geophyte, hemicryptophyte, phanerophyte, and therophyte). Target species were first decided by visual observation. For herbaceous species, their dominances were determined using quadrat methods. Each quadrat $(1 \mathrm{~m} \times 1 \mathrm{~m})$ was spaced at least $2 \mathrm{~m}$ apart from another along the transect for recording community composition (totaling 10 quadrats along one transect and three transects at each site). Weighted means of frequency and biomass of target species were sorted and used to assess their dominances. For shrubs, the line-point intercept method was conducted to calculate targeted species' frequency, height, and cover, which are represented by a "hit" (three transects at each site; a $20 \mathrm{~m}$ rope with ca. $1 \mathrm{~cm}$ diameter or a measuring tape was used), whose weighted means were sorted to determine the dominant species (Herrick et al., 2005). We also consulted an expert who has prior knowledge or research on the dominant species at the selected sites.

These species were divided into earlier flowering species and later flowering species groups based on blooming time (Table 1). According to Raunkiaer's life-form system, earlier flowering species mainly consisted of hemicryptophyte, geophyte, and phanerophyte, whereas more than half of later flowering species comprised chamaephyte. Nearly half of the tested species were dominant or co-dominant in their respective communities. The dry matter content of flower litters in all of the species was ranked from 10 to $60 \%$. Mixed leaf litters of alpine meadows were sampled on Mt. Kaka (3950 m a.s.l.), and leaf litters of 13 dominant species were collected to compare their chemical properties with flower litters. Both types of litters were first spread on blotting paper for air drying. A small portion of each litter was further dried in an oven for $48 \mathrm{~h}$ to calculate dry matter content.

\subsection{Experimental design}

Polyvinyl chloride (PVC) pots $(15 \mathrm{~cm}$ deep, $20 \mathrm{~cm}$ diameter at the top, and $12 \mathrm{~cm}$ diameter at the bottom) were filled with $2 \mathrm{~kg}$ of soils, which were collected in the autumn of 2011. The collected soil samples were stored at $4{ }^{\circ} \mathrm{C}$. The samples were sieved through a $2 \mathrm{~mm}$ mesh and then mixed thoroughly. The soil surface of each treatment was added with $5 \mathrm{~g}$ of flower litters or mixed litters (calculated as dry weight) on 21 June (14 species, earlier flowering plants) and $11 \mathrm{Au}-$ gust 2012 (15 species, later flowering plants). The surface was covered with a thin layer of soil to avoid being blown by wind. Another two additional treatments were conducted without litter addition (control) and with mixed leaf litter addition, respectively. In total, the pot experiment consisted of 33 treatments with 3 replicates, with a total number of 99 pots. All of the pots were carefully buried $12 \mathrm{~cm}$ deep into the field to maintain the same soil temperature in the experimental field. The pots were randomly distributed, and their top edges were approximately $3 \mathrm{~cm}$ above the ground to prevent runoff from outside. All of the pots were rearranged every week to create a similar microclimate. After 50 days, each soil sample was collected from three points of each pot in the center and then mixed to avoid the boundary layer effect. Each soil sample from different PVC pots was mixed evenly by sieving through a $2 \mathrm{~mm}$ mesh. The samples were stored and marked separately in an ice box prior to chemical determination.

\subsection{Decomposition rate}

A litter bag with a size of $14 \mathrm{~cm} \times 20 \mathrm{~cm}$ was used to determine the decomposition rate of different plant litters. The bag was double-faced and made from nylon net material with above $(4.5 \mathrm{~mm} \times 4.5 \mathrm{~mm}$ mesh $)$ and below $(0.8 \mathrm{~mm} \times 0.8 \mathrm{~mm}$ mesh) layers. The above layer with a larger mesh size allowed free access for most microarthropods, which dominate the soil fauna of alpine meadow on the eastern Tibetan Plateau, whereas the below layer with a smaller mesh size can reduce litter spillage from the litter bags in the process. As representative species, flower litters of Rhododendron przewalskii and Meconopsis integrifolia and mixed litter were packed into litter bags with the edges sealed on 21 June 2012. The litter-bag experiment was 
Table 1. General description of flower litters.

\begin{tabular}{|c|c|c|c|c|c|}
\hline & $\begin{array}{l}\text { Life } \\
\text { form }\end{array}$ & $\begin{array}{r}\text { Size of } \\
\text { inflorescence }(\mathrm{cm})\end{array}$ & $\begin{array}{r}\text { Dominant } \\
(\mathrm{Y} / \mathrm{N})\end{array}$ & Color & $\begin{array}{l}\text { Dry matter } \\
\text { content }(\%)\end{array}$ \\
\hline Caragana jubata & $\mathrm{C}$ & $1-1.5$ & $\mathrm{~N}$ & white & 29.81 \\
\hline Primula orbicularis & $\mathrm{H}$ & 1.5 & $\mathrm{Y}$ & yellow & 23.29 \\
\hline Potentilla anserina & G & $1-1.8$ & $\mathrm{Y}$ & yellow & 51.9 \\
\hline Rhododendron capitatum & $\mathrm{P}$ & $2-3$ & $\mathrm{Y}$ & purple & 32.84 \\
\hline Viola rockiana & $\mathrm{H}$ & 1 & $\mathrm{~N}$ & yellow & 25.22 \\
\hline Myricaria squamosa & $\mathrm{P}$ & $0.5-1$ & $\mathrm{~N}$ & pink & 30.95 \\
\hline Potentilla saundersiana & $\mathrm{G}$ & $1-1.4$ & $\mathrm{~N}$ & yellow & 54.01 \\
\hline Taraxacum lugubre & $\mathrm{H}$ & $3-4$ & $\mathrm{Y}$ & yellow & 14.97 \\
\hline Aster tongolensis & $\mathrm{H}$ & $4-5$ & $\mathrm{~N}$ & blue & 28.72 \\
\hline Cardamine tangutorum & $\mathrm{G}$ & $0.8-1.5$ & $\mathrm{~N}$ & lavender & 13.08 \\
\hline Spiraea alpina & $\mathrm{P}$ & $0.5-0.7$ & $\mathrm{Y}$ & fallow & 32.58 \\
\hline Caltha scaposa & $\mathrm{H}$ & $3-4$ & $\mathrm{Y}$ & yellow & 30.43 \\
\hline Rhododendron przewalskii & $\mathrm{P}$ & $4-5$ & $\mathrm{Y}$ & pink & 33.33 \\
\hline Meconopsis integrifolia & $\mathrm{H} / \mathrm{T}$ & $5-7$ & $\mathrm{~N}$ & yellow & 21.79 \\
\hline Stellera chamaejasme & $\mathrm{C}$ & 0.5 & $\mathrm{~N}$ & red & 28.11 \\
\hline Potentilla fruticosa & $\mathrm{P}$ & $2-3$ & $\mathrm{Y}$ & yellow & 30.43 \\
\hline Meconopsis punicea & $\mathrm{H} / \mathrm{A}$ & $5-8$ & $\mathrm{~N}$ & red & 33.57 \\
\hline Meconopsis violacea & $\mathrm{H}$ & $4-6$ & $\mathrm{~N}$ & purple & 35.70 \\
\hline Sibiraea angustata & $\mathrm{P}$ & 0.8 & $\mathrm{Y}$ & white & 29.50 \\
\hline Polygonum macrophyllum & $\mathrm{H}$ & 0.2 & $\mathrm{Y}$ & pink & 21.79 \\
\hline Pedicularis megalochila & $\mathrm{C}$ & $0.8-1$ & $\mathrm{~N}$ & red & 33.57 \\
\hline Ligularia virgaurea & $\mathrm{C}$ & 1.5 & $\mathrm{~N}$ & yellow & 16.78 \\
\hline Pilose Asiabell & $\mathrm{C}$ & $2-2.5$ & $\mathrm{~N}$ & pale/green & 22.26 \\
\hline Oxytropis ochrocephala & $\mathrm{C}$ & 1 & $\mathrm{~N}$ & fallow & 28.72 \\
\hline Pedicularis longiflora & $\mathrm{C}$ & 0.8 & $\mathrm{~N}$ & yellow & 28.11 \\
\hline Hedysarum vicioides & $\mathrm{C}$ & 1 & $\mathrm{~N}$ & pink & 30.02 \\
\hline Gentiana sino-ornata & $\mathrm{C}$ & $3-5$ & $\mathrm{Y}$ & purple & 44.10 \\
\hline Leontopodium sinense & $\mathrm{C}$ & $0.2-0.5$ & $\mathrm{Y}$ & white & 56.92 \\
\hline Cremanthodium lineare & $\mathrm{G}$ & $1.2-1.7$ & $\mathrm{Y}$ & yellow & 48.93 \\
\hline
\end{tabular}

Note: C, H, G, P, and T represent chamaephyte, hemicryptophyte, geophyte (one of the subdivided groups in cryptophytes), phanerophyte, and thermophile, respectively. $\mathrm{Y}$ and $\mathrm{N}$ indicate whether the species is dominant or not in the community. The first 14 species are earlier flowering species, and the other 15 species are later flowering species.

conducted to compare the decomposition rate of flower litters and mixed litter. Each treatment had eight replicates. After 7 weeks (8 August 2012), the debris or mud was removed outside the litter bags carefully, then litters were taken outside, sank into a small water basin for a short time, and sorted out clay and litter through a $0.5 \mathrm{~mm}$ mesh filter. Lastly, the remaining litters were dried in an oven for $48 \mathrm{~h}\left(65^{\circ} \mathrm{C}\right)$ and measured the weight on the balance (accuracy $0.001 \mathrm{~g}$ ) for decomposition calculation. Litter decomposition rates can be determined by the following equation:

$\mathrm{DR}=(P-R) / P \times 100$,

where DR is the decomposition rate, $P$ is primary litter mass in the litter bags, and $R$ refers to residue litter before determining percentage mass loss.

\subsection{Chemistry determination of soil and plant}

For soil samples, total dissolved $\mathrm{N}(\mathrm{TN})$ contents were determined using unsieved fresh moist soil subsamples. Soil subsamples were extracted using $2 \mathrm{M} \mathrm{KCl}$ and shaken for $1 \mathrm{~h}$ at room temperature $\left(20^{\circ} \mathrm{C}\right)$, with a soil-to-solution ratio of $1: 5$ (weight/volume). The extracted solution was filtered through filter paper before further determination (Jones et al., 2004). $\mathrm{NH}_{4}^{+}-\mathrm{N}$ and $\mathrm{NO}_{3}^{-}-\mathrm{N}$ were analyzed with the indophenol blue colorimetric (Sah, 1994) and ultraviolet spectrophotometry methods (Norman et al., 1985), respectively. Dissolved organic nitrogen (DON) was calculated by subtracting dissolved inorganic $\mathrm{N}\left(\mathrm{NH}_{4}^{+}-\mathrm{N}\right.$ and $\left.\mathrm{NO}_{3}^{-}-\mathrm{N}\right)$ from TN. Soil solutions were extracted by centrifugal drainage, whereas the exchangeable pool was extracted with $2 \mathrm{M} \mathrm{KCl}$ by using the methods reported by Jones et al. (2004). Total phosphorus (TP) consists of phosphorus mineral and organic phosphorous compounds in the soil, which can be converted into the dissolved orthophosphate. Available phos- 


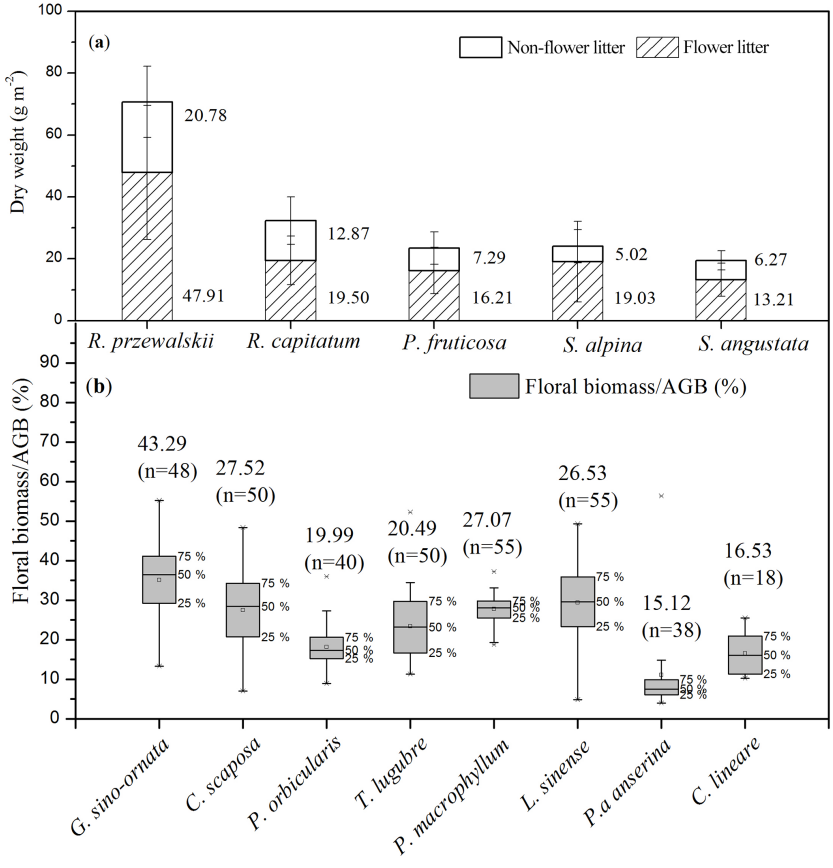

Figure 2. Production of flower litters and biomass allocation of representative dominant species. (a) Production of flower litters and non-flower litters of shrubs (phaenerophyte, $n=20$ ) per unit area $\left(\mathrm{m}^{2}\right)$, and (b) floral biomasses and their allocation in the aboveground biomass.

phorous (A-P) is the fragments in soil that can be absorbed by plants, which consist of water-soluble phosphorus, some adsorbed phosphorus, organic phosphorus, and precipitated phosphorus in certain soil types. Chemically, A-P is defined as the phosphorus and phosphate in a soil solution that can be isotope exchanged with ${ }^{32} \mathrm{P}$ or can be easily extracted by some chemical reagents. TP and A-P in soils were estimated by extraction with $0.5 \mathrm{M}$ sodium hydroxide sodium carbonate solution (Dalal, 1973). Microbial biomass carbon (MBC) and microbial biomass nitrogen (MBN) contents were determined through the chloroform-fumigation direct-extraction technique. Correction factors of 0.54 for $\mathrm{N}$ and 0.45 for $\mathrm{C}$ were used to convert the chloroform labile $\mathrm{N}$ and $\mathrm{C}$ to microbial N and C (Brookes et al., 1985). For plant samples, the contents of $\mathrm{C}$ and $\mathrm{N}$ were determined by dry combustion with a CHNS auto-analyzer system (Elementar Analysen Systeme, Hanau, Germany; Brodowski et al., 2006). The content of $\mathrm{P}$ was obtained colorimetrically by the chloromolybdophosphoric blue color method after wet digestion in a mixture of $\mathrm{HNO}_{3}, \mathrm{H}_{2} \mathrm{SO}_{4}$, and $\mathrm{HClO}_{4}$ solution (Institute of Soil Academia Sinica, 1978). Lignin and cellulose were estimated by the method described by Melillo et al. (1989).

\section{Data analysis}

One-way ANOVA was applied to compare values between the treatments and the control. Post hoc multiple comparisons were adopted when the groups were three or more. Multivariate ANOVA was conducted to determine the effects of blooming time and different addition of litters and their interactions. To simplify the comparison of soil $\mathrm{N}$ and $\mathrm{P}$ between control (without flower litter) and the treated group (with flower litter), we defined an index $\alpha$ as $\alpha=\mathrm{Ln}$ $\left(\mathrm{N}_{2} / \mathrm{N}_{1}\right) . \alpha>0, \mathrm{~N}_{2}>\mathrm{N}_{1} ; \alpha<0, \mathrm{~N}_{2}<\mathrm{N}_{1} ; \alpha=0, \mathrm{~N}_{2}=\mathrm{N}_{1}$. $\mathrm{N}_{1}$ is the control treatment without flower litter, and $\mathrm{N}_{2}$ indicated the nutrition value ( $\mathrm{N}$ or $\mathrm{P}$ ) of flower litter treatment. Descriptive analysis was operated to demonstrate the $\alpha$ values of different $\mathrm{N}$ and $\mathrm{P}$ fragments in various species litter addition treatments. The box plots provide the distribution of the values by the medians (central line), the 25 and $75 \%$ quartiles (box), and the ranges (whiskers). Asterisks (*) represent the distribution of extreme outliers. The values (mean, $n=X$ ) are also stated by one-way ANOVA. For comparison of three or more groups, mean differences were tested at $P<0.05$ by using a Tukey multiple-range test in the SPSS 19.0 software package (SPSS Inc., Chicago, IL, USA). The normality of data was tested with a one-sample $K-S$ test and a Q-Q plot. Otherwise, log-transformation was adopted to meet the normality requirement. Homogeneity of the variance test was also utilized during the analysis. In the figures and tables, information is presented as means and standard errors of means. All of the differences were tested at the $P=0.05$ level.

\section{Results}

\subsection{Flower litter production of dominant species and their biomass allocation}

Among 13 dominant species, the flower litters of phenerophyte plants, whose flower litters are comparable with non-flower litters, were calculated through comparison with non-flower litters in the process of flower litter collection (Fig. 2a). The dry weights of flower litters were 10 $40 \mathrm{~g} \mathrm{~m}^{-2}$, whereas their non-flower litters were only 5$25 \mathrm{~g} \mathrm{~m}^{-2}$. Although neither of the flower litters of $S$. angustata or $R$. capitatum were significantly different compared with their non-flower litters $(P>0.05)$, the difference between the two remained noticeable, whose values were $28.03 \pm 3.56 \mathrm{~g} \mathrm{~m}^{-2}$ vs. $13.21 \pm 1.49 \mathrm{~g} \mathrm{~m}^{-2}$ for $R$. capitatum and $19.58 \pm 3.50 \mathrm{~g} \mathrm{~m}^{-2}$ vs. $12.95 \pm 0.61 \mathrm{~g} \mathrm{~m}^{-2}$ for $S$. angustata. The production of flower litters was higher than that of non-flower litters. The other three species significantly produced more flower litters than non-flower litters (R. przewalskii: $F=15.76, P<0.001 ;$. fruticosa: $F=4.76, P<0.05$; S. alpine: $F=10.18, P<0.01)$. The flower litters of the eight herbaceous species were compared with their individ- 
Table 2. $\alpha$ values of soil $\mathrm{N}$ and $\mathrm{P}$ pools in various species litters' addition treatment $(n=14$ and $n=15$ in earlier flowering species and later flowering species, respectively). TP and A-P are total phosphorus and available phosphorus, respectively. $\alpha$ values indicate the natural logarithm of the ratio of flower litter addition to non-addition control of different soil indexes (i.e., $\mathrm{TN}, \mathrm{NO}_{3}^{-}-\mathrm{N}, \mathrm{NH}_{4}^{+}-\mathrm{N}$, $\mathrm{TP}$, and $\mathrm{A}-\mathrm{P}$; the same below).

\begin{tabular}{llrrrrrr}
\hline Flowering period & Index & Mean & Std. error & Minimum & Maximum & $F$ & $P$ \\
\hline \multirow{2}{*}{ Earlier flowering } & $\mathrm{TN}$ & 1.67 & 0.06 & 1.29 & 2.05 & 719.05 & 0.000 \\
& $\mathrm{NO}_{3}^{-}-\mathrm{N}$ & 1.67 & 0.07 & 1.08 & 2.23 & 563.90 & 0.000 \\
& $\mathrm{NH}_{4}^{+}-\mathrm{N}$ & 0.97 & 0.12 & 0.42 & 2.06 & 68.25 & 0.000 \\
& $\mathrm{TP}$ & 0.02 & 0.03 & -0.04 & 0.08 & 8.498 & 0.007 \\
& $\mathrm{~A}-\mathrm{P}$ & 0.31 & 0.17 & 0.67 & 0.13 & 47.39 & 0.000 \\
\hline \multirow{2}{*}{ Later flowering } & $\mathrm{TN}$ & 1.29 & 0.21 & -0.37 & 2.40 & 38.37 & 0.000 \\
& $\mathrm{NO}_{3}^{-}-\mathrm{N}$ & 1.11 & 0.18 & -0.75 & 1.55 & 37.77 & 0.000 \\
& $\mathrm{NH}_{4}^{+}-\mathrm{N}$ & 0.36 & 0.05 & -0.09 & 0.72 & 60.64 & 0.000 \\
& $\mathrm{TP}^{-0.03}$ & 0.03 & 0.11 & -0.20 & 0.12 & 0.97 & 0.33 \\
& $\mathrm{~A}-\mathrm{P}$ & 0.50 & 0.23 & 0.06 & 0.37 & 68.82 & 0.000 \\
\hline
\end{tabular}

Table 3. Multifactorial analysis of variance for the effects of flowering time, litter addition, and their interactions on soil $\mathrm{N}$ and $\mathrm{P}$ pools.

\begin{tabular}{lrr|r|r|rr|rr|r|r|r}
\hline Source of variation & \multicolumn{2}{c|}{$\mathrm{TN}$} & \multicolumn{2}{|c|}{$\mathrm{NO}_{3}^{-}-\mathrm{N}$} & \multicolumn{2}{|c|}{$\mathrm{NH}_{4}^{+}-\mathrm{N}$} & \multicolumn{2}{|c|}{$\mathrm{TP}$} & \multicolumn{2}{c}{ A-P } \\
\cline { 2 - 10 } & $F$ & $P$ & $F$ & $P$ & $F$ & $P$ & $F$ & $P$ & $F$ & $P$ \\
\hline Corrected model & 59.25 & 0.00 & 69.24 & 0.00 & 54.07 & 0.00 & 1.07 & 0.37 & 43.01 & 0.00 \\
Flowering time & 2.80 & 0.10 & 7.93 & 0.01 & 24.36 & 0.00 & 0.02 & 0.90 & 6.44 & 0.01 \\
Litter addition treatments & 173.47 & 0.00 & 194.34 & 0.00 & 117.00 & 0.00 & 3.17 & 0.08 & 114.14 & 0.00 \\
Flowering time $\times$ & 2.80 & 0.10 & 7.93 & 0.01 & 24.36 & 0.00 & 0.02 & 0.90 & 6.44 & 0.01 \\
Litter addition treatments & & & & & & & & & & \\
\hline
\end{tabular}

Note: $P$ values for significant effects and interactions are in bold (at the level $P=0.05$ ).

ual aboveground biomass (Fig. 2b), which ranged from 10 to nearly $40 \%$. This finding indicated that flower litter should be considered to determine the effect of plants on the soil nutrition pool during the growing season.

\subsection{Comparison of chemical properties between flower and leaf litters}

Total C content was not significantly different between flower and leaf litters (Fig. 3a, $F=1.80, P=0.199$ ). However, the levels of cellulose, lignin, and structure $\mathrm{C}$ of leaf litter were significantly higher than those of flower litter $(F=6.74, P<0.05 ; F=5.77, P<0.05 ; F=10.99$, $P<0.01)$. Hence, flower litter probably contains more nonstructure $\mathrm{C}$ than leaf litter.

Both $\mathrm{N}$ and $\mathrm{P}$ contents of flower litters were significantly higher than those of leaf litters (Fig. 3b). $\mathrm{N}$ in flower litters was nearly doubled to that of leaf litter $(23.17 \pm 1.52,11.87 \pm 0.77 ; F=45.70, P<0.001)$. More than twice the amount of $\mathrm{P}$ was also present in flower litters $\left(2.95 \pm 0.25 \mathrm{~g} \mathrm{~kg}^{-1}\right)$ compared with that in leaf litters $\left(1.12 \pm 0.12 \mathrm{~g} \mathrm{~kg}^{-1} ; F=43.87, P<0.001\right)$.

For the implication of the ratio of different chemical properties, $\mathrm{C} / \mathrm{N}, \mathrm{N} / \mathrm{P}$, and lignin / $\mathrm{N}$ were determined to com- pare flower and leaf litters. All three indicators of leaf litter were significantly higher than those of flower litters (Fig. 3c). As parameters used to demonstrate decomposition rate, $\mathrm{C} / \mathrm{N}$ and lignin / $\mathrm{N}$ of leaf litter were nearly double those of flower litter $(39.27 \pm 4.16,19.80 \pm 1.39, F=37.78$, $P<0.001 ; 21.09 \pm 2.25,12.79 \pm 1.15, F=7.91, P<0.01$ ). Furthermore, the $\mathrm{N} / \mathrm{P}$ of flower litter was significantly higher than that of leaf litter $(8.42 \pm 0.42,11.60 \pm 0.56$; $F=20.62, P<0.001)$. These findings indicated that flower litter can supply more $\mathrm{P}$ per unit $\mathrm{N}$ than leaf litter.

\subsection{Assessing the effects of flower litter on soil N pool and $P$ pool}

Earlier flowering species exerted positive effects on soil TN, $\mathrm{NO}_{3}^{-}-\mathrm{N}$, and $\mathrm{NH}_{4}^{+}-\mathrm{N}$ (Fig. 4a), with the addition of their flower litters according to their size of $\alpha$ values. Most parameters were higher than 0 , which indicated that $\mathrm{N}_{2}>\mathrm{N}_{1}$. Flower litter increased the soil $\mathrm{N}$ pool. All of the minimum $\alpha$ values of the five indices were also higher than 0 (Table 2 , $0.42-1.29$ ), which indicated that flower litter addition significantly increased the soil $\mathrm{N}$ pool, including different fragments $(P<0.001)$. Among the later flowering species, except G. sino-ornata and $L$. sinense, soil $\mathrm{N}$ indices were signifi- 

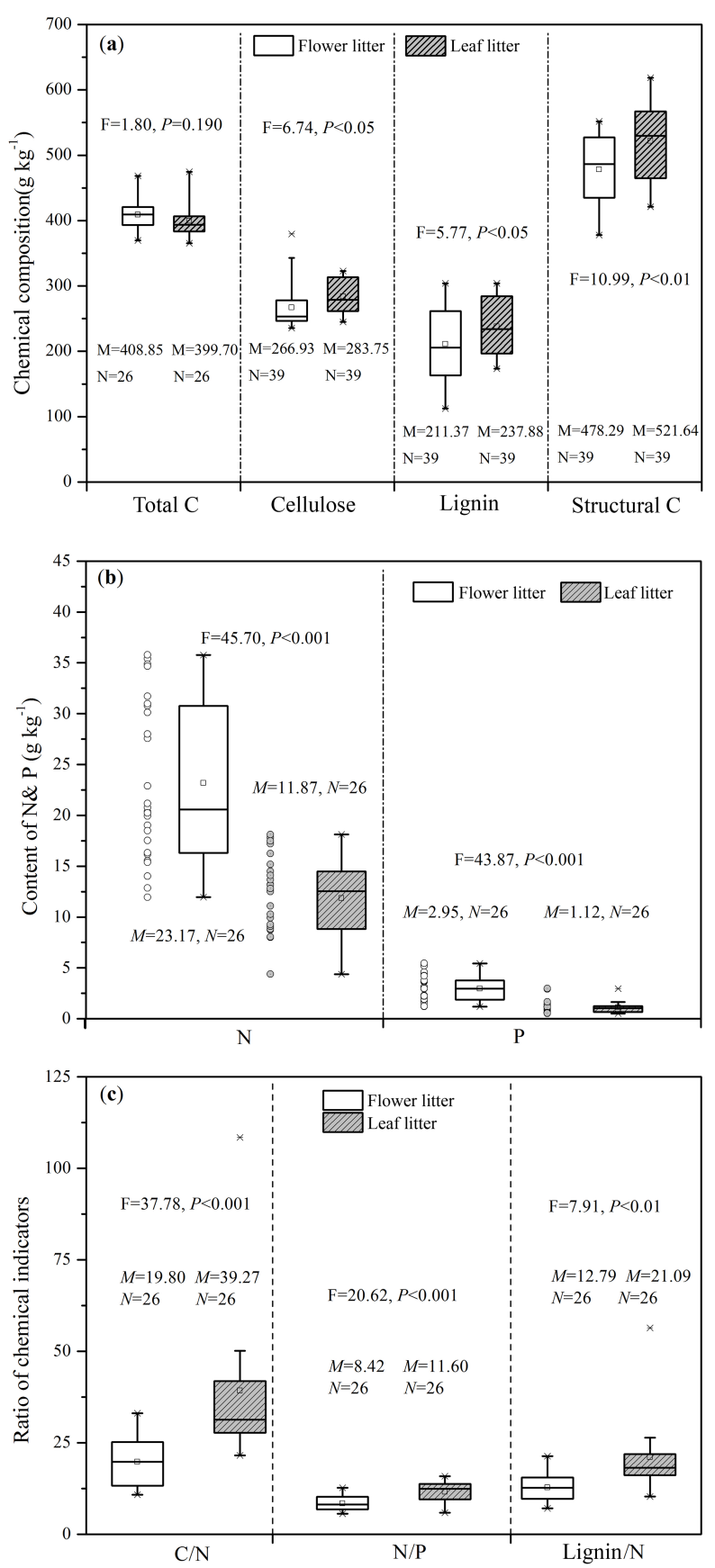

Figure 3. Chemical composition and their comparison between flower and leaf litters. Whiskers refer to quantiles for comparable data settings. Asterisks $(*)$ represent the distribution of extreme outliers. $M=$ mean and $N$, which indicates the data/sample number, are analyzed and processed by one-way ANOVA (at the $P=0.05$ level).

cantly improved with flower litter addition, as demonstrated through $\alpha$ values higher than 0 (Fig. 4b, Table 2). Later flowering species differed from earlier flowering species, with minimum $\alpha$ values lower than 0 , which resulted from the exceptions of G. sino-ornata and $L$. sinense. However, all of the mean $\alpha$ values were higher than 0 , which presented general results after flower litter addition (0.36-1.49); the soil $\mathrm{N}$ pool was significantly enhanced only after 50 days $(P<0.001)$. Interactions between flowering time and litter addition for $\mathrm{NO}_{3}^{-}-\mathrm{N}$ and $\mathrm{NH}_{4}^{+}-\mathrm{N}$ were significant $(F=5.043, P<0.05$; $F=7.947, P<0.01 ; F=24.143, P<0.05$, respectively) but not for TN $(F=0.470, P=0.496)$. Different flowering times significantly affected $\mathrm{NO}_{3}^{-}-\mathrm{N}$, and $\mathrm{NH}_{4}^{+}-\mathrm{N}$ (Table 3 , $P<0.01)$ but did not significantly influence TN $(F=2.80$, $P=0.10)$. As illustrated in Fig. 4, litter addition had significant effects on all of the $\mathrm{N}$ fragments, which was in accordance with the results in Table 3 . The interaction of flowering time and litter addition exerted similar effects on the soil $\mathrm{N}$ pool as well as its $\mathrm{N}$ fragments with flowering time solely.

Flower litters exerted different effects on soil TP and AP. Soil TP increased in treatment with early flowering litters (Fig. 4a, Table 2, $F=8.498, P=0.007$ ) but not in later flowering litters (Fig. $4 \mathrm{~b}$, Table $2, F=0.97, P=0.33$ ). The minimum $\alpha$ values were lower than $0(-0.04$ and -0.20 , respectively). However, the A-P of both litter treatments was significantly positively stimulated $(F=47.39, P<0.001$; $F=68.82, P<0.001)$, whose $\alpha$ values were both higher than 0 (0.67-0.13 and 0.06-0.37, respectively). Multifactorial analysis indicated that soil TP was not significantly different between the sample treated with flower litter and the control (Table 3, $F=1.07, P=0.37$ ). No significant interaction was evident between flowering time and litter addition treatments on soil TP $(F=0.01, P=0.93)$. Litter addition treatments alone only had a marginal significant effect on soil $\mathrm{TP}(F=3.17, P=0.08)$. Moreover, both minimum $\alpha$ values were lower than 0 , but TP was not significantly different between treatments with later flowering litters and control treatment $(F=0.97, P=0.33)$, which mainly resulted from $G$. sino-ornata, L. sinense, and C. lineare. Nevertheless, A-P increased significantly after flower litter addition $(F=43.01$, $P<0.001$ ), with a significant interaction between flowering time and litter addition $(F=6.44, P<0.05)$.

\subsection{Effects of flower litter addition on the soil solution $\mathrm{N}$ pool and soil MBC and MBN}

The soil solution $\mathrm{N}$ pool has been improved noticeably from 31.46 to $47.35 \mathrm{mg} \mathrm{g}^{-1}$ in flower litter treatment compared with the control, particularly in the fragment of $\mathrm{NO}_{3}^{-}-\mathrm{N}$, which has been greatly increased (from 30.93 to $46.8 \mathrm{mg} \mathrm{g}^{-1}$; Table 4). In mixed leaf litter treatment, no obvious variations were found after litter decomposition, with $32.4 \mathrm{mg} \mathrm{g}^{-1} \mathrm{NO}_{3}^{-}-\mathrm{N}$ and $0.45 \mathrm{mg} \mathrm{g}^{-1} \mathrm{NH}_{4}^{+}-\mathrm{N}$, respectively. Notable differences in both MBC and MBN were found between different treatments. Litter addition increased not only soil microbial biomass C $\left(102.05,68.08\right.$, and $46.25 \mathrm{mg} \mathrm{kg}^{-1}$ for flower litter, mixed litter, and control, respectively) and MBN $\left(73.02,69.29,67.13 \mathrm{mg} \mathrm{kg}^{-1}\right.$ for flower litter, mixed litter, and control, respectively) but also their $\mathrm{C} / \mathrm{N}$ ratios 

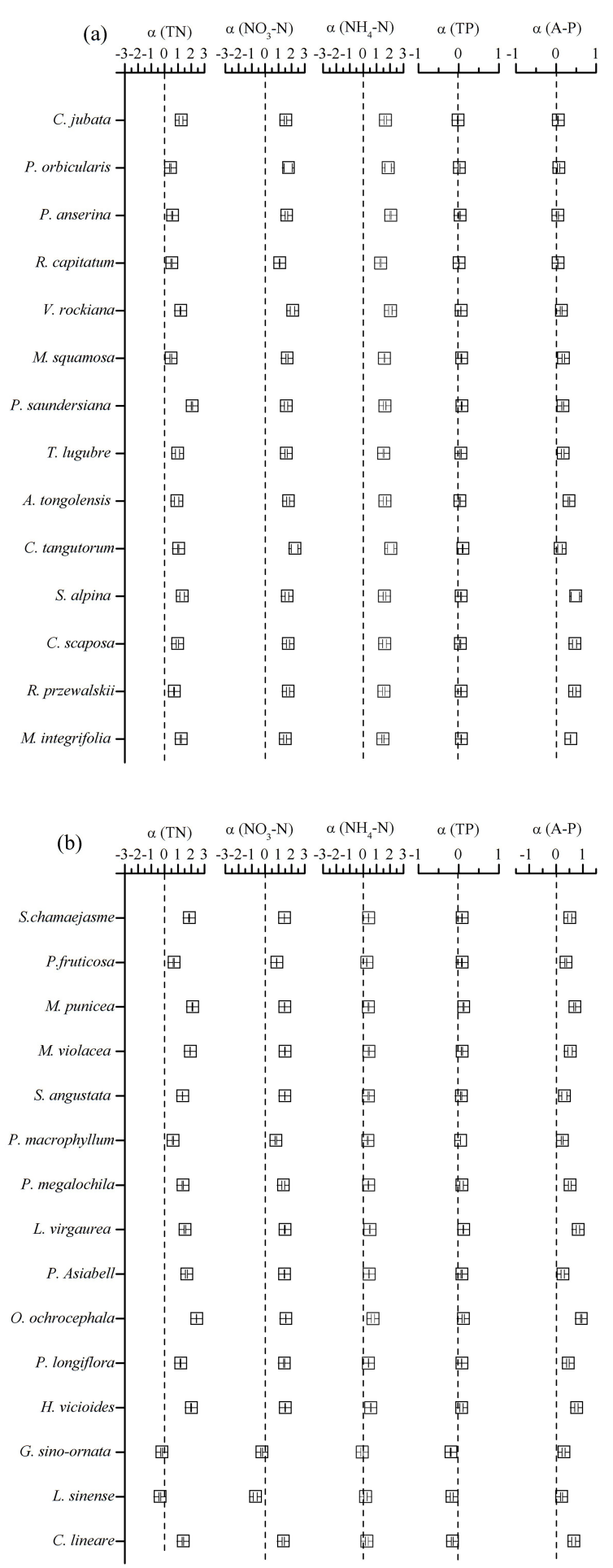

Figure 4. Variation in the soil $\mathrm{N}$ pool and $\mathrm{P}$ pool after addition of flower litters, (a) earlier flowering species, and (b) later flowering species. Scatters represent $\alpha$ mean values of different indexes. Significant differences of deviations from the 0 lines are tested at the $P=0.05$ level $(n=3)$. TN, $\mathrm{NO}_{3}-\mathrm{N}, \mathrm{NH}_{4}-\mathrm{N}, \mathrm{TP}$, and A-P represent total nitrogen, nitrate nitrogen, ammonium nitrogen, total phosphorus, and available phosphorus, respectively.
Table 4. Comparison of the mean values of the soil solution pool and soil microbial biomass between litter addition treated (flower litter and mixed leaf litter) and control.

\begin{tabular}{lrr|rrr}
\hline Treatments & \multicolumn{2}{c|}{$\begin{array}{c}\text { Soil solution } \mathrm{N} \\
\text { pool }\left(\mathrm{mg} \mathrm{g}^{-1}\right)\end{array}$} & \multicolumn{3}{|c}{$\begin{array}{c}\text { Soil microbial } \\
\text { biomass }\left(\mathrm{mg} \mathrm{kg}^{-1}\right)\end{array}$} \\
\cline { 2 - 6 } & $\mathrm{NO}_{3}^{-}-\mathrm{N}$ & $\mathrm{NH}_{4}^{+}-\mathrm{N}$ & $\mathrm{MBC}$ & $\mathrm{MBN}$ & $\mathrm{MBC} / \mathrm{MBN}$ \\
\hline Flower litter & 46.8 & 0.55 & 102.05 & 73.02 & 1.40 \\
Mixed leaf litter & 32.4 & 0.45 & 68.08 & 69.29 & 0.98 \\
Control & 30.93 & 0.53 & 46.25 & 67.13 & 0.69 \\
\hline
\end{tabular}

(1.40, 0.98, and 0.69 for flower litter, mixed litter, and control, respectively).

\subsection{Comparison of decomposition rate between flower litter and mixed leaf litter}

R. przewalskii and $M$. integrifolia are two typical plant species widely distributed and easily collected. Both species were assessed to compare decomposition rates of their flower litter and mixed leaf litter. Differences in decomposition rate among the flower litter of two species and mixed litter were supposed to be significant (Fig. 5, $F=130.34, P<0.001$ ). The flower litters of $R$. przewalskii and $M$. integrifolia decomposed much faster than mixed leaf litter. Moreover, within only 50 days, more than $20 \%$ of $R$. przewalskii and $M$. integrifolia flower litters decomposed, whereas the decomposition rate for mixed leaf litter was approximately $6 \%$ only (i.e., the former was nearly 3 times faster). Moreover, no significant differences were evident in the decomposition rates of the flower litter of $R$. przewalskii and $M$. integrifolia $(P=0.371)$.

\section{Discussion}

Plant litter decomposition is a critical step in the formation of SOM, mineralization of organic nutrients, and $\mathrm{C}$ balance in terrestrial ecosystems (Austin and Ballaré, 2010; Cotrufo et al., 2015). At an early stage of decomposition, there exists partial correlation between decomposed plant material and light fraction in the SOM pool at a transitional stage of the humification process (Leifeld and Kögel-Knabner, 2005). Species-specific variations in plant phenology can affect production of litter fall, which is noticeable during the growing season from the aspect of nutrient cycling, although the peak of litter fall happens in autumn (the Northern Hemisphere). Thus, the early litter fall of alpine plants during the study period from May to August can be a potential nutrient source when nutritional demands increase for rapid growth and development. In particular, the amount of flower fall in the study area exceeds the leaf fall during the blooming season. A previous study indicated that reproductive litter production accounted for $<10 \%$ of the total litter in January-August and $13-26 \%$ in September-December (Sanches et al., 2008), 


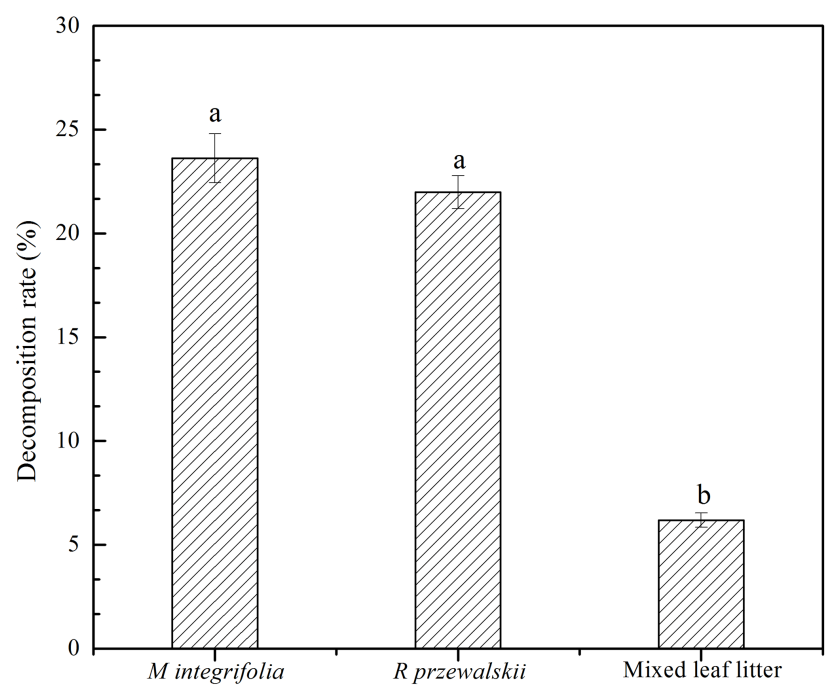

Figure 5. Percentage of decomposed dry mass of $M$. integrifolia and $R$. przewalskii in a 50-day litter-bag study. Column represents the mean, and bar indicates the standard error $(n=8)$. Different lowercase letters indicate significant differences of the decomposition rate between litter materials (at the $P=0.05$ level).

which was mainly triggered by rainfall variability that directly altered litter production dynamics and indirectly altered forest floor litter. In addition, the flowers are more nutritional than the leaves in terms of nutrients necessary for plant growth (Lee et al., 2011). In this study, summit production of flower litters booms during special periods for both earlier flowering and later flowering species. Flower biomass of herbaceous plants accounts for $10 \%$ to approximately $40 \%$ of total aboveground biomass. Moreover, these flower litters were produced considerably earlier than other aboveground litters that dropped at the end of the growing season. Furthermore, flower litters and non-flower litters (mainly constituted of leaves) of woody plants were $10-40$ and $5-25 \mathrm{~g} \mathrm{~m}^{-2}$, respectively, which clearly implies that flower litter can be a comparable decomposition substrate in alpine ecosystems, even for phenerophyte plants.

Litter production and decomposition are controlled by biological and physical processes, such as the activity and composition of soil and litter fauna and climate variations (Meentemeyer, 1978; Cornejo et al., 1994; Wieder and Wright, 1995; Aerts, 1997; Cleveland et al., 2004). An integration of index or traits has been recommended to indicate the process and rate of litter decomposition. Generally, tissues with high lignin, polyphenol, and wax contents and higher lignin / $\mathrm{N}$ and $\mathrm{C} / \mathrm{N}$ ratios exhibit slow decomposition. Lignin / $\mathrm{N}$ and $\mathrm{C} / \mathrm{N}$ ratios are commonly accepted as good indicators of decomposition rates under short time frames; however, there is minimal conclusive evidence that lignin is preferentially preserved in soils compared with bulk soil over long time periods (Melillo et al., 1982; Aber et al., 1990; Mikutta et al., 2005; Kleber et al., 2007; Cotrufo et al., 2015). More- over, lignin plays a dual role in plant litter decomposition when photochemical mineralization and abiotic decomposition are considered (Austin and Ballaré, 2010). Leaf litter with $\mathrm{C} / \mathrm{N}$ ratios lower than 30 is known to decompose easily and yield a mull humus type, whereas $\mathrm{C} / \mathrm{N}$ ratios above 30 result in $\mathrm{N}$ immobilization (Heal et al., 1997) and decomposition retardation. In this study, flower litter had a significantly lower $\mathrm{C} / \mathrm{N}$ ratio $(19.80 \pm 1.39$, less than 30) than leaf litter (39.27 \pm 4.16 , more than 30). Structural (lignin, DMC) and chemical $(\mathrm{N})$ traits are proposed to be better predictors for several high-turnover organs than structural traits alone (Freschet et al., 2012). Lignin content in flower litters was significantly less than that in leaf litters $\left(211.37 \pm 8.63\right.$ and $237.88 \pm 6.89 \mathrm{mg} \mathrm{kg}^{-1}$, respectively; $F=5.77, P=0.02)$, similar to cellulose $(266.93 \pm 4.92$ and $283.75 \pm 4.21 \mathrm{mg} \mathrm{kg}^{-1}$, respectively; $F=6.74, P=0.01$ ), which is one of the major cell wall constituents. All of the results are in accordance with previous studies. Decomposition rate is negatively correlated with the concentration of lignin, which is a group of complex aromatic polymers that serves as a structural barrier impeding microbial access to labile $\mathrm{C}$ compounds (Swift et al., 1979; Taylor et al., 1989; Austin and Ballaré, 2010; Talbot and Treseder, 2012). Moreover, the absence of significant differences of total $\mathrm{C}$ content in flower litters but with significantly fewer structural carbohydrates than those in leaf litters indicated that greater non-structural carbohydrates existed in flower litters. This finding can be inferred from the contents of lignin and cellulose (Fig. 3a). Hence, flower litters can promote nutrients that easily complement soil (Parton et al., 2007) for plants in their entire life history. Decomposition rates of leaf litters have been considered recently from their lignin / $\mathrm{N}$ or lignin/cellulose (Talbot and Treseder, 2012; Cornwell et al., 2008). Furthermore, in the present study, lignin / $\mathrm{N}$ was less in flower litters (almost $50 \%$ in leaf litters, i.e., $12.79 \pm 1.15$ and $21.09 \pm 2.25$, respectively), whereas N / P was higher than that of leaf litters.

A litter-bag experiment on two widely distributed dominant shrubs (R. przewalskii and $M$. integrifolia) confirmed that the decay rates of flower litters were significantly faster than those of other litters, which is in accordance with the fast decomposition of $R$. pseudoacacia flower from an experiment performed in Korea (Lee et al., 2010). Flower litters contained significantly higher $\mathrm{N}$ and $\mathrm{P}$ contents than leaf litters (Fig. 3b). Plant litter available to the decomposer community encompasses a broad range of issues that differ in chemical and physical properties (Swift et al., 1979). P has been regarded as essential for a long time, which leads to limited attention to mechanisms that drive $\mathrm{P}$ limitation and their interactions with the $\mathrm{N}$ cycle (Vitousek et al., 2010). In most soils, the concentration of orthophosphate in solution is low (Richardson et al., 2009). Although soil generally contains a large amount of total P, only a small proportion is immediately available for plant uptake from the soil solution. $\mathrm{P}$ is derived mainly from rock weathering and the related biogeochemical cycle, and ecosystems begin their existence with a 

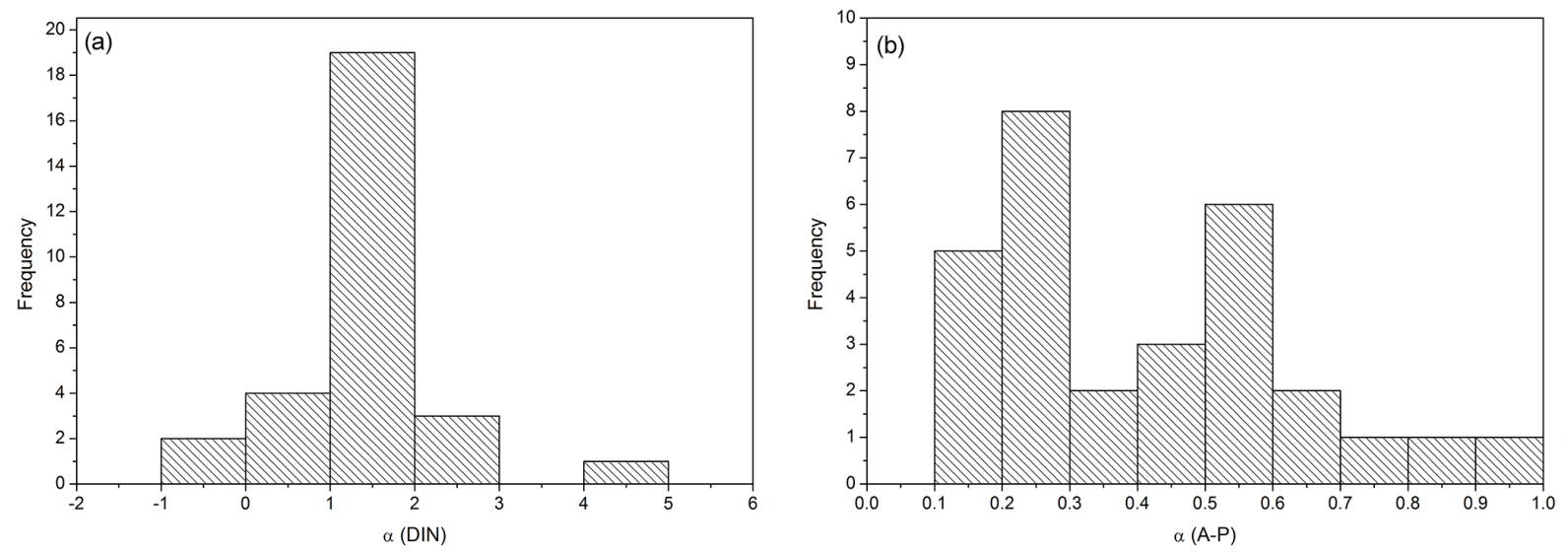

Figure 6. Variation in the soil nutrition pool with flower litter addition. The histogram for $\alpha$ values of DIN (a) and A-P (b) indicates the change between treatments and control.

fixed complement of $\mathrm{P}$, and even very small losses cannot be readily replenished (Walker and Syers, 1976). The present study indicated that decomposition of flower litter can be one of the beneficial sources of soil A-P in alpine ecosystems. Decomposition rates can be markedly affected by particle size, surface area, and mass characteristics (Angers and Recous, 1997). In addition, physical toughness (lignin, dry matter content, or $\mathrm{C}$ content) can be a suitable predictor of decomposition across all of the organs. Nevertheless, the current study regarding the characteristics and driving mechanism of this source remains at the first stage. Variation in soil physical-chemical properties, vegetation types, and microbial activities can significantly affect chemical compositions and forms as well as the biological availability of soil P directly or indirectly.

Decay rates of different plant organs reflect the diversity that fruits decompose faster than leaves, which in turn decompose faster than woody plant parts (Swift et al., 1979; Kögel-Knabner, 2002). Flower litters decompose rapidly with higher $\mathrm{N}$ and $\mathrm{P}$ levels supplied to soil, particularly from $\mathrm{NO}_{3}^{-}-\mathrm{N}$ in the soil solution pool (Table 4). The histogram for $\alpha$ values of DIN and A-P also presented soil available nutrients positively stimulated by flower litter (Fig. 6) for their values distributed at an interval greater than 0 . The high DOC values in flower litter may influence $\mathrm{N}$ and $\mathrm{P}$ in soil through the $\mathrm{C}$ substrate supplement for soil microorganisms to enhance $\mathrm{N}$ immobilization. Recent empirical studies noted that the changing microbial community composition significantly affects ecosystem processes, such as litter decomposition (Strickland et al., 2009; Ramirez et al., 2012). Shifts from bacterial-dominated to fungal-dominated decomposition happened over short (days to a few months) periods (Poll et al., 2008; McMahon et al., 2005). Although the present study did not present the precise analysis of the microbial community, both MBC and MBN differed greatly between different treatments (Table 4). Litter addition increased them obviously, which is evident not only in microbial biomass $\mathrm{C}$ and $\mathrm{N}$, but also in their $\mathrm{C} / \mathrm{N}$ ratios $(1.40,0.98$, and 0.69 for flower litter, mixed litter, and control, respectively). Flower litter contains more than twice the MBC (increased from 46.25 to 102.05 ), and both MBC and MBN pools increased potentially after flower litter addition. Therefore, microbial functional groups might be changed for nutrient supplement from litters or could also be due to their faster turnover or growth, which need more evidence in further study by directly testing soil microbial community composition.

Several unexpected species in the experiment reduced soil available nutrients, probably because their specific chemical properties, which change as a result of microbial activities and nutrient dynamics (Karmarkar and Tabatabai, 1991), may negatively affect soil microorganism biomass or activities (Wardle et al., 1998; Cipollini et al., 2012). Furthermore, soil microbial communities can be modified through time in response to allelopathic plants, with known or potential effects on plant communities (Cipollini et al., 2012; Inderjit, 2001). Soil carbon generally is divided into pools with varying intrinsic decomposition rates in turnover models, whose decomposition rates can be modified and codetermined by interaction between substrates, microbial actors, and abiotic driving variables. These factors are rationalized by assuming chemical structure is a primary controller of decomposition (Kleber et al., 2010). Most of the non-fertilizer $\mathrm{N}$ source needed for plant growth is SOM (Sollins et al., 2007), which consists of organic molecular fragments with wide-ranging amphiphilicity degrees, intimately contacting mineral surfaces of variable chemical reactivity and a polar solvent. Mineralization and nitrification can be subdued by inhibitory compounds from the exudates of a certain plant species, which come from a negative aspect and mainly result from suppression of related microbes (Cipollini et al., 2012). In another positive perspective, considering the "priming effect" once flower litter is added in moderate treatments 
causes strong short-term changes in the turnover of SOM, and nutrient release follows litter decomposition (Jenkinson et al., 1985; Kuzyakov et al., 2000; Blagodatskaya and Kuzyakov, 2008). Hence, $\mathrm{N}$ and $\mathrm{P}$ availability in the soil of alpine ecosystems can be maintained in part by tissue chemistry favorable to microbial decomposition and release of nutrients.

Flower litter influences different fractions in soil $\mathrm{N}$ and $\mathrm{P}$ pools as well as soil microbial biomass (i.e., MBC and MBN), which provided evidence that plant species, through tissue chemistry, biomass allocation, and phenology, affect local soil properties and SOM formation in alpine ecosystems. Soil has a specific susceptibility to decomposition of biochemical compounds in plant tissues, on a spectrum from quickly decomposed labile to relatively recalcitrant. Flower litters have intuitive benefits chemically and physically for the formation, stabilization, and mineralization process of SOM. In future studies, major scientific findings and also potential questions less studied previously should be highlighted, and scientific obstacles should be considered to further address the stabilization and destabilization of SOM in this field. In brief, under a changing climate and a steadily increasing service demand in the alpine ecosystems, it is essential to understand the mechanisms underlying SOM stabilization. Furthermore, soil carbon models would benefit from taking flower litters' decomposition with specific attribution into soil nutrition pools. Flower litters affect carbon and nutrient cycling and should be incorporated into SOM pools along with decomposition simultaneously, which should be enhanced in future studies to better understand the essentiality and fundamentality of litter decomposition.

\section{Data availability}

The data set related to this study has been provided as a supplement.

\section{The Supplement related to this article is available online at doi:10.5194/bg-13-5619-2016-supplement.}

Acknowledgements. This study was financially supported by the International Cooperation Project of Science and Technology Department of Sichuan Province (2014HH0056), the China Postdoctoral Science Foundation (2014M552385), and the National Natural Science Foundation of China (31400389). We would like to acknowledge the Key Lab of Ecological Restoration and Biodiversity Conservation of Sichuan (ECORES) for their support in laboratory facilities. We all appreciate that Jiceng Xu revised the sampling sites on the map.

Edited by: R. Conant

Reviewed by: two anonymous referees

\section{References}

Aber, J. D. and Melillo, J. M.: Litter decomposition: measuring relative contributions of organic matter and nitrogen to forest soils, Can. J. Bot., 58, 416-421, 1980.

Aber, J. D., Melillo, J. M., and Mcclaugherty, C. A.: Predicting Long-Term Patterns of Mass-Loss, Nitrogen Dynamics, and Soil Organic-Matter Formation from Initial Fine Litter Chemistry in Temperate Forest Ecosystems, Can. J. Bot., 68, 2201-2208, 1990.

Aerts, R.: Climate, leaf litter chemistry and leaf litter decomposition in terrestrial ecosystems: A triangular relationship, Oikos, 79, 439-449, 1997.

Angers, D. A. and Recous, S.: Decomposition of wheat straw and rye residues as affected by particle size, Plant Soil., 189, 197203, 1997.

Arroyo, M. T. K., Pacheco, D. A., and Aguilera, P.: Floral allocation at different altitudes in highly autogamous alpine Chaetanthera euphrasioides (Asteraceae) in the central Chilean Andes, Alpine Bot., 123, 7-12, 2013.

Austin, A. T. and Ballaré, C. L.: Dual role of lignin in plant litter decomposition in terrestrial ecosystems, P. Natl. Acad. Sci. USA, 107, 4618-4622, 2010.

Berendse, F. and Aerts, R.: Nitrogen-use-efficiency:A Biologically Meaningful Definition, Funct. Ecol. 1, 293-296, 1987.

Berg, B. and Ekbohm, G.: Nitrogen Immobilization in Decomposing Needle Litter at Variable Carbon - Nitrogen Ratios, Ecology, 64, 63-67, 1983.

Bieleski, R. L.: Phosphate Pools, Phosphate Transport, and Phosphate Availability, Annu. Rev. Plant Phys., 24, 225-252, 1973.

Blagodatskaya, D. V. and Kuzyakov, Y.: Mechanisms of real and apparent priming effects and their dependence on soil microbial biomass and community structure: critical review, Biol. Fertil. Soils, 45, 115-131, 2008.

Brodowski, S., John, B., Flessa, H., and Amelung, W.: Aggregateoccluded black carbon in soil, Eur. J. Soil Sci., 57, 539-546, 2006.

Brookes, P. C., Landman, A., Pruden, G., and Jenkinson, D. S.: Chloroform fumigation and the release of soil nitrogen: a rapid direct extraction method to measure microbial biomass nitrogen in soil, Soil Biol. Biochem., 17, 837-842, 1985.

Buxton, D. R. and Marten, G. C.: Forage Quality of Plant-Parts of Perennial Grasses and Relationship to Phenology, Crop. Sci., 29, 429-435, 1989.

Chapin, F. S., Vitousek, P. M., and Vancleve, K.: The Nature of Nutrient Limitation in Plant-Communities, Am. Nat., 127, 4858, 1986.

Chapin, F. S.: Effects of plant traits on ecosystem and regional processes: a conceptual framework for predicting the consequences of global change, Ann. Bot., 91, 455-463, 2003.

Chinese Soil Taxonomy Research Group: Chinese Soil Taxonomy, China Agriculture Scientech Press, 1995.

Cipollini, D., Rigsby C. M., and Barto, E. K.: Microbes as targets and mediators of allelopathy in plants, J. Chem. Ecol., 38, 714 727, 2012.

Cleveland, C. C., Neff, J. C., Townsend, A. R., and Hood, E.: Composition, dynamics, and fate of leached dissolved organic matter in terrestrial ecosystems: Results from a decomposition experiment, Ecosystems, 7, 275-285, 2004. 
Cornejo, F. H., Varela, A., and Wright, S. J.: Tropical Forest Litter Decomposition under Seasonal Drought: Nutrient Release, Fungi and Bacteria, Oikos, 70, 183-190, 1994.

Cornwell, W. K., Cornelissen, J. H. C., Amatangelo, K., Dorrepaal, E., Eviner, V. T., Godoy, O., Hobbie, S. E., Hoorens, B., Kurokawa, H., Perez-Harguindeguy, N., Quested, H. M., Santiago, L. S., Wardle, D. A., Wright, I. J., Aerts, R., Allison, S. D., van Bodegom, P., Brovkin, V., Chatain, A., Callaghan, T. V., Diaz, S., Garnier, E., Gurvich, D. E., Kazakou, E., Klein, J. A., Read, J., Reich, P. B., Soudzilovskaia, N. A., Vaieretti, M. V., and Westoby, M.: Plant species traits are the predominant control on litter decomposition rates within biomes worldwide, Ecol. Lett., 11, 1065-1071, doi:10.1111/j.1461-0248.2008.01219.x, 2008.

Cotrufo, M. F., Soong, J. L., Horton, A. J., Campbell, E. E., Haddix, M. L., Wall, D. H., and Parton, W. J.: Formation of soil organic matter via biochemical and physical pathways of litter mass loss, Nat, Geosci., 8, 776-779, 2015.

Dalal, R. C.: Estimation of Available Phosphorus in Soils by Extraction with Sodium Hydroxide Sodium Carbonate Solution, J. Aust. Ins. Agr. Sci., 39, 142-143, 1973.

Fabbro, T. and Korner, C: Altitudinal differences in flower traits and reproductive allocation, Flora, 199, 70-81, 2004.

Freschet, G. T., Aerts, R., and Cornelissen, J. H. C.: A plant economics spectrum of litter decomposability, Funct Ecol., 26, 5665, 2012.

Grime, J. P.: Benefits of plant diversity to ecosystems: immediate, filter and founder effects, J. Ecol., 86, 902-910, 1998.

Groffman, P. M.: Carbon additions increase nitrogen availability in northern hardwood forest soils, Biol Fertil. Soils., 29, 430-433, 1999.

Hautier, Y., Randin, C. F., Stocklin, J., and Guisan, A.: Changes in reproductive investment with altitude in an alpine plant, J. Plant. Ecol.-UK, 2, 125-134, 2009.

Haynes, R. J.: Mineral Nitrogen in the Plant-Soil System (Physiological Ecology), Academic Press Inc, 1986.

Heal, O. W., Anderson, J. M., and Swift, M. J.: Plant litter quality and decomposition: an historical overview, in: Driven by nature, Plant litter quality and decomposition, edited by: Cadisch, G. and Giller, K. E., CAB International, Wallingford, 3-30, 1997.

Herrick, J. E., Van Zee, J. W., Havstad, K. M., Burkett, L. M., and Whitford, W. G.: Monitoring manual for grassland, shrubland and savanna ecosystems, Volume I: Quick Start, Volume II: Design, supplementary methods and interpretation, USDA-ARS Jornada Experimental Range, 2005.

Inderjit, W. J.: Plant allelochemical interference or soil chemical ecology?, Perspect. Plant Ecol., 4, 3-12, 2001.

Institute of Soil Academia Sinica: Analysis of soil physical and chemical property, Shanghai scientific and technical publishers, Shanghai, 1978.

Jenkinson, D. S., Fox, R. H., and Rayner, J. H.: Interactions between fertilizer $\mathrm{N}$ and soil $\mathrm{N}$ : the so-called priming effect, Eur. J. Soil Sci., 36, 425-444, 2006.

Jones, D. L., Shannon, D., Murphy, D. V., and Farrar, J.: Role of dissolved organic nitrogen (DON) in soil $\mathrm{N}$ cycling in grassland soils, Soil Biol. Biochem., 36, 749-756, 2004.

Karmarkar, S. V. and Tabatabai, M. A.: Effects of biotechnology byproducts and organic acids on nitrification in soils, Biol. Fertil. Soils, 12, 165-169, 1991.
Kleber, M., Sollins, P., and Sutton, R.: A conceptual model of organo-mineral interactions in soils: self-assembly of organic molecular fragments into zonal structures on mineral surfaces, Biogeochemistry, 85, 9-24, 2007.

Kleber, M., Nico, P. S., Plante, A., Filley, T., Kramer, M., Swanston, C., and Sollins, P.: Old and stable soil organic matter is not necessarily chemically recalcitrant: implications for modeling concepts and temperature sensitivity, Glob. Change Biol., 17, 10971107, 2010.

Kuzyakov, Y., Friedel, J. K., and Stahr, K.: Review of mechanisms and quantification of priming effects, Soil Biol. Biochem., 32, 1485-1498, 2000.

Kögel-Knabner, I.: The macromolecular organic composition of plant and microbial residues as inputs to soil organic matter, Soil Biol Biochem., 34, 139-162, 2002.

Körner, C.: Alpine plant life: functional plant ecology of high mountain ecosystems, 2nd Edn., Springer, Berlin, New York, 2003.

Laungani, R. and Knops, J. M. H.: Species-driven changes in nitrogen cycling can provide a mechanism for plant invasions, P. Natl, Acad, Sci., 106, 12400-12405, 2009.

Leifeld, J. and Kögel-Knabner, I.: Soil organic matter fractions as early indicators for carbon stock changes under different landuse?, Geoderma, 124, 143-155, 2005.

Lee, Y. C., Nam, J. M., and Kim, J. G.: The influence of black locust (Robinia pseudoacacia) flower and leaf fall on soil phosphate, Plant Soil., 341, 269-277, 2011.

Martínez-Yrízar, A., Núñez, S., Miranda, H., and Búrquez, A.: Temporal and spatial variation of litter production in Sonoran Desert communities, Plant Ecol., 145, 37-48, 1999.

MacLean, D. A. and Wein, R. W.: Litter production and forest floor nutrient dynamics in pine and hardwood stands of New Brunswick, Canada, Ecography, 1, 1-15, 1978.

Mcmahon, S. K., Williams, M. A., Bottomley, P. J., and Myrold, D. D.: Dynamics of microbial communities during decomposition of carbon-13 labeled ryegrass fractions in soil, Soil Sci. Soc. Am. J., 69, 1238-1247, 2005.

Meentemeyer, V.: Macroclimate and Lignin Control of Litter Decomposition Rates, Ecology, 59, 465-472, 1978.

Melillo, J. M., Aber, J. D., and Muratore, J. F.: Nitrogen and Lignin Control of Hardwood Leaf Litter Decomposition Dynamics, Ecology, 63, 621-626, 1982.

Melillo, J. M., Aber, J. D., Linkins, A. E., Ricca, A., Fry, B., and Nadelhoffer, K. J.: Carbon and nitrogen dynamics along the decay continuum: plant litter to soil organic matter, Plant Soil., 115, 189-198, 1989.

Mikutta, R., Kleber, M., Kaiser, K., and Jahn, R.: Review: organic matter removal from soils using hydrogen peroxide, sodium hypochlorite, and disodium peroxodisulfate, Soil Sci. Soc. Am. J., 69, 120-135, 2005.

Muller-Landau, H. C. and Wright, S. J.: Litterfall Monitoring Protocol, 2010.

Nilsson, C., Xiong, S. J., Johansson, M. E., and Vought, L. B. M.: Effects of leaf-litter accumulation on riparian plant diversity across Europe, Ecology, 80, 1770-1775, 1999.

Norman, R. J., Edberg, J. C., and Stucki, J. W.: Determination of Nitrate in Soil Extracts by Dual-wavelength Ultraviolet Spectrophotometry, Soil Sci. Soc. Am. J., 49, 1182-1185, 1985. 
Parton, W., Silver, W. L., Burke, I. C., Grassens. L., Harmon, M. E., Currie, W. S., King, J. Y., Adair, E. C., Brandt, L. A., Hart, S. C., and Fasth, B.: Global-scale similarities in nitrogen release patterns during long-term decomposition, Science, 315, 361-364, 2007.

Poll, C., Marhan, S., Ingwersen, J., and Kandeler, E.: Dynamics of litter carbon turnover and microbial abundance in a rye detritusphere, Soil Biol. Biochem., 40, 1306-1321, 2008.

Ramirez, K. S., Craine, J. M., and Fierer, N.: Consistent effects of nitrogen amendments on soil microbial communities and processes across biomes, Glob. Change Biol., 18, 1918-1927, 2012.

Richardson, A. E., Barea, J. M., McNeill, A. M., and PrigentCombaret, C.: Acquisition of phosphorus and nitrogen in the rhizosphere and plant growth promotion by microorganisms, Plant Soil, 321, 305-339, 2009.

Sah, R. N.: Nitrate-Nitrogen Determination-A Critical Review, Commun. Soil Sci. Plan., 25, 2841-2869, 1994.

Sanches, L., Valentini, C. M. A., Pinto, O. B., Nogueira, J. D., Vourlitis, G. L., Biudes, M. S., da Silva, C. J., Bambi, P., and Lobo, F. D.: Seasonal and interannual litter dynamics of a tropical semideciduous forest of the southern Amazon Basin, Brazil, J. Geophys. Res.-Biogeo., 113, G04007, doi:10.1029/2007JG000593, 2008.

Scott, N. A., Cole, C. V., Elliott, E. T., and Huffman, S. A.: Soil textural control on decomposition and soil organic matter dynamics, Soil Sci. Soc. Am. J., 60, 1102-1109, 1996.

Sollins, P., Swanston, C., and Kramer, M.: Stabilization and destabilization of soil organic matter - a new focus, Biogeochemistry, 85, 1-7, 2007.

Strickland, M. S., Lauber, C., Fierer, N., and Bradford, M. A.: Testing the functional significance of microbial community composition, Ecology, 90, 441-451, 2009.

Stohlgren, T. J.: Litter dynamics in two Sierran mixed conifer forests, II. Nutrient release in decomposing leaf litter, Can. J. Forest Res., 18, 1136-1144, 1988.
Swift, M. J., Heal, O. W., and Anderson, J. M.: Decomposition in Terrestrial Ecosystems, University of California Press, Berkeley, CA, 1979.

Talbot, J. M. and Treseder, K. K.: Interactions among lignin, cellulose, and nitrogen drive litter chemistry-decay relationships, Ecology, 93, 345-354, 2012.

Taylor, B. R., Parkinson, D., and Parsons, W. F. J.: Nitrogen and lignin content as predictors of litter decay rates a microcosm test, Ecology, 70, 97-104, 1989.

Vitousek, P. M. and Howarth, R. W.: Nitrogen Limitation on Land and in the Sea - How Can It Occur, Biogeochemistry, 13, 87$115,1991$.

Vitousek, P. M., Porder, S., Houlton, B. Z., and Chadwick, O. A.: Terrestrial phosphorus limitation: mechanisms, implications, and nitrogen-phosphorus interactions, Ecol Appl., 20, 5-15, 2010.

Walker, T. W. and Syers, J. K.: Fate of phosphorus during pedogenesis, Geoderma, 15, 1-19, 1976.

Wardle, D. A., Zackrisson, O., and Nilsson, M.-C.: The charcoal effect in boreal forests: mechanisms and ecological consequences, Oecologia, 115, 419-426, 1998.

Wieder, R. K. and Wright, S. J.: Tropical Forest Litter Dynamics and Dry Season Irrigation on Barro-Colorado Island, Panama, Ecology, 76, 1971-1979, 1995.

Wookey, P. A., Aerts, R., Bardgett, R. D., Baptist, F., Brathen, K. A., Cornelissen, J. H. C., Gough, L., Hartley, I. P., Hopkins, D. W., Lavorel, S., and Shaver, G. R.: Ecosystem feedbacks and cascade processes: understanding their role in the responses of Arctic and alpine ecosystems to environmental change, Glob. Change Biol., 15, 1153-1172, 2009.

Xiong, S. J. and Nilsson, C.: The effects of plant litter on vegetation: a meta-analysis, J. Ecol., 87, 984-994, 1999.

Yavitt, J. B. and Fahey, T. J.: Litter Decay and Leaching from the Forest Floor in Pinus-Contorta (Lodgepole Pine) Ecosystems., J. Ecol., 74, 525-545, 1986. 